\title{
A new subdisarticulated machaeridian from the Middle Devonian of China: Insights into taphonomy and taxonomy using X-ray microtomography and 3D-analysis
}

Benjamin Gügel, Kenneth De Baets, Iwan Jerjen, Philipp Schuetz, and Christian Klug Acta Palaeontologica Polonica 62 (2), 2017: 237-247 doi:https://doi.org/10.4202/app.00346.2017

Machaeridians are an extinct group of armoured annelids, which are mainly known from isolated sclerites present from the Ordovician to the Permian. Based on articulated specimens with preserved soft-tissues and trace fossils, derived machaeridians are interpreted to have an infaunal burrowing mode of life. However, the taphonomy of sclerite associations is still largely unstudied. We herein investigated associated sclerites from the Middle Devonian of China using micro-computer tomography and 3D-analysis. These sclerites belong to a single individual and lie in close proximity. The absence of indications for current alignment, major bioturbation or other processes causing a disarticulation as reflected in the randomly arranged dacryoconarids suggest that the sclerites became disarticulated in the course of the normal decay processes, perhaps aided by scavenging and incomplete burial. The unique morphology of the sclerites indicates that the specimen presented here belongs to a previously undescribed species, which we describe herein as Lepidocoleus kuangguoduni sp. nov.

Key words: Annelida, Lepidocoleidae, tomography, SPIERS, taphonomy, Devonian, Nandan-Formation, Guangxi, China.

Benjamin Gügel [benjamin.guegel@gmail.com] and Kenneth De Baets [kenneth.debaets@fau.de ] (corresponding author), Geozentrum Nordbayern, Friedrich-Alexander Universität Erlangen-Nürnberg, Loewenichstraße 28, 91054 Erlangen, Germany. Iwan Jerjen [iwan.jerjen@psi.ch ], Department of Information Technology and Electrical Engineering, ETH Zürich, Gloriastrasse 35, 8092 Zürich, Switzerland. Philipp Schuetz [philipp.schuetz@hslu.ch ], Technik \& Architektur, Hochschule Luzern, Technikumstrasse 21, 6048 Horw, Switzerland. Christian Klug [chklug@ pim.uzh.ch], Paläontologisches Institut und Museum, Universität Zürich, Karl-Schmid-Strasse 4, 8006 Zürich, Switzerland. 
This is an open-access article distributed under the terms of the Creative Commons

Attribution License (for details please see creativecommons.org), which permits unrestricted use, distribution, and reproduction in any medium, provided the original author and source are credited.

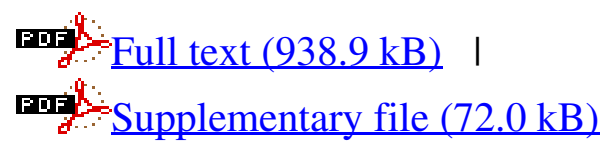

